MAGDA WÄCHTER

\title{
"HOW DO WE HAPPEN TO BE INSPIRED?" LITERATURE SURVEYS FROM THE 1930s
}

Besides classical conceptions of artistic inspiration prevalent in the realms of aesthetics, poetics or the philosophy of culture, a series of lesser theories that regard creation as part of the banal, quotidian existence were advanced in and around the turn of the twentieth century. In parallel with the type of speculative discourse found in systematic constructs, there appeared, thus, approaches that pursued a spirit of authenticity, such as dialogic reflection, spontaneous, relaxed replies, and light, unconventional confession, unfettered by the rigours of formality or by gender distinctions. The lack of literariness, typically associated with professions of faith, represents the first guarantee of the veracity of this type of text, which offers itself as a simple record of one's spiritual or emotional experience, without any claims to artistic value. That explains the abundance of surveys on the topic of creation conducted especially in the interwar period, when a broad array of literary trends could often engage in fecund disagreement. "The most formidable and the most revolting period in the history of this country", as Gherasim Luca defines it ${ }^{1}$, was one of contrasts, reflected at the level of the literary works, of literary creeds, but also of the myriad theories of inspiration, nurtured by a variety of factors and endowed with extremely rich cognitive potential.

Under the title "Why Do You Write?" the literary review Facla launched a survey in 1935, after the example of French publications like Littérature or Commune. The result was a genuine novel about writing, anticipating the "Corinthian" novel, comprising over two hundred characters and including pages of "high spiritual tension", but also of "true human comedy", as Victor Durnea notices in the preface of his book ${ }^{2}$. How is literature, literary criticism or the writer's craft seen by those authors turned characters? How do they see inspiration? Is it a spontaneous act, a simple or a complex emotion, or the fruit of ceaseless reflection? Is writing meant to compensate for personal shortcomings or to serve a general purpose? Does it derive from excess or from scarcity? Is the writer aware of his mission or, rather, subjected to a fatality whose most intimate mechanisms cannot be conveyed? Finally, how does an author see himself in the mirror? How does the one who meditates on creation see the one who creates?

All these questions are addressed in the writers' responses, which seem to be following, from the outset, two main strategies: interrogation and negation. The

\footnotetext{
${ }^{1}$ Gheorghe Hrimiuc-Toporaş, Victor Durnea (eds.), „De ce scrieţi?” Anchete literare din anii '30 ["Why Do You Write?" Literary Surveys from the 1930s]. Foreword, notes and name index by Victor Durnea, Iaşi, Polirom, 1998, p. 39.

2 Ibidem, p. 7.
} 
former concerns the very legitimacy of literary surveys, as a possible frontier species related to literature. Radu Boureanu, for instance, believes that a simple newspaper column is inadequate for a profession of faith that involves the disclosure of a highly complex universe, reflected in "endless parallel mirrors"3. Similarly, Saşa Pană tentatively expresses himself in favour of this type of investigation, in a concessive manner: "surveys are good (with all the harshness of a name that is reminiscent of councils of war and inquisitorial magistrates), when the answers avoid being literary..."4. In fact, delimitations from literature represent a constant concern of the so-called "new generation" whose members are fully asserting themselves at this time as a gesture of protest against the values of their predecessors. "You know very well that we are a generation that doesn't really like literature", Pericle Martinescu declares sententiously. "It would be safe to assume that we don't like it at all. We prefer spiritual, ideological battles; we like bitter controversies, with an impact on reality; we like things that require fanaticism, passion, struggle and risk. Literature seems too insignificant, it bores us, it's too devoid of life"s. An intense debate on a topical theme, albeit with literary implications, is more favourably seen than obsolete works of fiction that "intoxicated" the minds of earlier scholars. However, very many writers remain silent when it comes to questions concerning the intimate springs of creation. To some, such questions appear to be both trite and crucial (Dan Petrașincu); to others - too brutal (Tudor Arghezi), or too serious and bold (Virgil Carianopol), if not downright senseless (Mircea Damian). Şerban Cioculescu believes that the survey should not be addressed to literary critics, objective and impersonal researchers, who are not authors of documents that record spiritual or emotional experiences. For critics, the question would have "an epigrammatic character", and their answer would be devoid of any kind of importance ${ }^{6}$. In another context, Perpessicius states that he is simply overwhelmed, while several other writers confess that they are at a loss. Those who accept the challenge often speak from a position of uncertainty, vagueness or even contradict themselves, stepping across the boundaries of literature, of criticism, of pure judgement, and even of morals. Besides circumventing the question by claiming that it is impossible to provide an answer, the problem is transferred to many different other areas, ranging from trivial facts to social or metaphysical issues.

Some respondents speak, for instance, about heredity, atavism, the spirit of imitation, about a fatality of writing that is impossible to explain (Tudor Vianu), about a physiological need or a possible cure for insomnia. According to Mihail Sebastian, the issue demands "a sum of short, ridiculous, simple and varied

\footnotetext{
${ }^{3}$ Ibidem, p. 42.

${ }^{4}$ Ibidem, p. 31.

${ }^{5}$ Ibidem, p. 106

${ }^{6}$ Ibidem, p. 95.
} 
answers"7. George Mihail Zamfirescu writes so as to stop feeling alone, Emil Gulian - for the satisfaction that he can always talk about himself, Gib Mihăescu because he likes it and it amuses him, Victor Ion Popa - to spend some extra energy, Horia Oprescu - to rest and in the hope that he will be admired... Some of the shorter confessions are of real historical and literary interest. Ion Barbu, for instance, recounts that he began to write for a single reader, Tudor Vianu, whom he admired with some envy while he was a student. Others reveal their sheer pleasure of mocking replies: Al. Robot writes so that he can pay for his coffee, Ion SânGiorgiu - because he is obssessed, Neagu Rădulescu - so that everyone will recognize him in the street, to conquer women and to be included in future textbooks, Ion-Aurel Manolescu, a nineteen-year old writer, - because he cannot stand school. Even great writers are not always spared the temptation of providing terribly trite replies. Eugen Lovinescu believes that it is all he is good at; Mircea Eliade regrets that he cannot split firewood; Camil Petrescu has nothing else to do; Eugen Ionescu deals with literature out of habit, a bad habit or a vice, for that matter, and because of his inability to become a politician or a philosopher. In his turn, Felix Aderca writes by mistake and with "bleak despair", hoping to be able to abandon one day the "infernal" tools, that is, the book and the pen", so as to become a tinsmith, a painter or a ploughman. Such assertions remind one of young Eliade's views (he was convinced of the "inadequacy of literature" Cioran's nihilism (he believed that he was a "scribe" lost in the world of Letters because of his inability to kill someone else or himself ${ }^{10}$.

Prose writers of the caliber of Victor Eftimiu harbour the belief that they lack any literary vocation; others, on the contrary, are fully aware of their own talent. Devotees of the idea of socially responsible art, just like the supporters of art for art's sake, they solemnly formulate their beliefs, talking either about the social role of creation, or about its mystical significance. Philosophising, Mihail Dan sees the poet as an initiate, the "slave" of a Kantian principle, concerned about "the affirmative will of metaphor"11. Poetically, Radu Gyr answers that he writes because "the Apollonian divinity shook a paradisiacal branch" over his shoulder. Camil Petrescu leaves himself at the mercy of inspiration for metaphysical reasons; he is disgusted every time he sees his works published, while Şerban Cioculescu compares the eternal values literature can reach with those of sacredness.

Many authors regard the act of creation, rather emphatically, as a harrowing, arduous occupation, or as self-flagellation. Ironically, others, like Mihail Sebastian,

\footnotetext{
${ }^{7}$ Ibidem, p. 47.

${ }^{8}$ Ibidem, p. 116.

${ }^{9}$ Mircea Eliade, "Insuficienţa literaturii” ["The Insufficiency of Literature"], in Profetism românesc [Romanian Profetism], I, București, Roza vânturilor, 1990, pp. 43-47.

${ }^{10}$ Emil Cioran, Caiete I (1957-1965) [Notebooks I (1957-1965)]. Foreword by Simone Boué. Translated from the French by Emanoil Marcu and Vlad Russo, Bucureşti, Humanitas, 1999-2000, p. 10.

${ }^{11}$ Gheorghe Hrimiuc-Toporaş, Victor Durnea (eds.), „De ce scrieţi”?, p. 50.
} 
are wondering whether there is any contemporary writer who is "so tragic, so tormented, so demoniacally enthralled that writing becomes for him an act of rescue without which he might die" 12 . Claiming to be driven by a charitable impulse, Ion Pas addresses an exhortation to these young artists: "Stop writing, stop bothering, gentlemen!" 13

Pertaining to the most varied registers, from a mere physiological act to psychology, philosophy, mysticism, sociology or political economy, the answers hesitate, inevitably, between the dramatic and the ridiculous, between a moralphilosophical stance and artistic playfulness. But what clearly emerges at a glance is the prevalence of denial over assertion. Not only do writers not appear to believe in their creative mission, but they harbour the conviction that writing reflects feelings of deep sadness and hopelessness, tentatively striving to compensate for a precarious existence. For example, Hortensia Papadat-Bengescu resorts to this solution out of desperation, fear and obsession; Anişoara Odeanu - to repress the need to cry; Mircea Vulcănescu - in times of inner crisis and, sometimes, of schizophrenia. Emil Botta does it without passion, without love, without grace, in exasperation and disgust, with the feeling that writing is tantamount to suicide. The authors-characters confess that they are incapable of living life, that they believe a writer is an assassinated man of action, and that they cannot embrace a different occupation, get along with their peers, that they experience shyness, loneliness, and anguish. Few are those who declare their faith in their own forces or in the value of the printed word. To them literature seems to be some sort of weakness, bad fortune or punishment. Skeptically, Petru Comarnescu regrets that people cannot understand one another through writing and that trying to communicate with others leads to almost nothing; Haig Acterian believes that writing is doomed to become a cliché, to deform thought, and he concludes, echoing Cioran, that "the illiterate person is the only one who inherits the truth"14. Petru Manoliu considers himself to be a man with a single desire, that of not becoming a writer.

The survey examining the springs of writers' inspiration turns out to be, ultimately, an occasion for criticism against creation, against Romanian writers in general, against the entire landscape of Romanian culture and, especially, against the other respondents. Noting that the question turned out to be useless for at least ninety-nine percent of authors, Al. O. Teodoreanu seizes the opportunity to call his fellows "morons", "assholes" and "mountebanks"15. In a calmer tone, other writers deplore the Romanian writers' lack of ideals, "the eternal plague of our literature" $"$. Criticism, self-criticism, the devaluation of writing, and the anti-

\footnotetext{
${ }^{12}$ Ibidem, p. 47.

${ }^{13}$ Ibidem, p. 61.

${ }^{14}$ Ibidem, p. 132.

${ }^{15}$ Ibidem, p. 103.

${ }^{16}$ Ibidem, p. 74.
} 
literary profession of faith are the main coordinates of this brief novel about writing conveyed in the form of a chronicle of the times.

Sometimes literary works can partly be found in the authors' replies, as it happens in the case of the supporters of socially committed art, of religious aesthetics or of the surrealist poets. The defying attitude and the shocking rhetoric of the latter are fully recognizable. Thus, Gherasim Luca writes from a sensibility "riddled with serious and inadmissible questions" in a century "of revolt and utter volatility" $"$. The young Eugen Ionescu's views on literature are already well known; so is the pose adopted sumptuously by Ion Minulescu, who writes to get his enemies bored and out of a need to possess his readers and critics. At other times, however, the statements reveal a surprising degree of inconsistency with the works and prestige of the authors. It is not clear how honest or how ironical the confessions of Eugen Lovinescu, Felix Aderca, Paul Zarifopol and Mircea Eliade are when they claim that they write because they are not good at anything else. The overall tone, the structure and length of the responses, rendered in a seemingly arbitrary succession, are, in their turn, disconcerting. A simple "I don't know" alternates with ample, fastidious or lyrical declarations, not devoid of self-pastiche, as in the case of Virgil Carianopol: "I write, gentlemen, because I love my anxiety, I write to vanquish myself, for my memories, for my life, for my factory brethren [...], for plants, for humanity, for the 30 years that I've wasted, for my blood, which springs from the extinct volcanoes of my parents" ${ }^{18}$. Other texts abound in theoretical considerations on creation, systematised from a historical, sociological, aesthetic or psychoanalytical perspective. In the end, however, the same question marks are raised.

To sum it all up, the mechanisms of artistic inspiration are far from being unravelled. Is creation an organic necessity, a pastime, a fatality, or an expression of divine grace? Does it come from a "Kantian principle", from an "Apollonian" calling, or from the humble desire of an individual to pay for a cup of coffee? Is writing a hellish occupation, an error, a curse, or the reflection of an aspiration towards the absolute? Are Romanian writers driven by an awareness of their own vocation or do they harbour hidden feelings of hopelessness, despair and disgust? Finally, do Romanian writers believe in the value of literature or, on the contrary, do they find it obsolete and utterly futile? Behind the artistic creeds consisting largely of interrogations, negations, paradoxes and contradictions, there is still a definite affirmative poetics. One of the suggestions, for instance, refers to the impossibility of dissociating the response from the creative act itself, viewed as the only adequate expression of the problem discussed. Without being an a priori given, inspiration represents therefore the intimate dynamics of writing and is impossible to dissociate from it. "Never, if we ask that question, will we discover

\footnotetext{
${ }^{17}$ Ibidem, p. 39

${ }^{18}$ Ibidem, p. 85.
} 
the essence", says Petre Boldur, because "true reality lies in the fact"19. Motivation resides, therefore, in the essence, and it is simultaneously revealed and concealed in the very temporality of writing. Any book is, ultimately, a reiteration of this question and a new search for an answer, as Hortensia Papadat-Bengescu also believes. If a writer knew why he writes, he would probably not do it at all, as Coca Farago and Emil Gulian believe, among others. At the end of the survey, Henriette Yvonne Stahl notes that none of those interviewed answered the question because there can be no definitive response. If we could answer as we should, says the prose writer, "it would mean that we have arrived at the primordial essence, and drew near to God" ${ }^{20}$. Few are indeed those who at least try to provide a plausible and carefully structured explanation. Mocking playfulness, irony, and self-pastiche are the faces of the absence of a unique and final recipe for creative imagination.

Some respondents theorise the idea of writing as a miracle, as a manifestation of the lack of the absolute or as a "special meaning" which cannot be explained by the writers themselves. The necessity of creation, Dan Petrașincu says, comes from an array of powers that are generally unfathomable. "The unplumbed elements are always the ones that create the 'destiny' of the writer, whether one of talent, of genius or a failure". Others see the intimate fabric of inspiration as a state that is incomprehensible rationally, one that is connected with what is known as the "inner self". Camil Baltazar invokes a state of grace meant to convey what is essential and durable in the privacy of the self through the practice of a new sense, associated with self-expansion and generosity. For Mircea Vulcănescu, the same mysterious special sense aspires to definitively give shape to some states of mind and, thus, to maintain the continuity of the self in spite of relativity. There are also voices that see the act of literary invention as a form of transcendence of outer reality, as full interiorisation or as "an antidote against the vulgar reality" and the only possible way to exist in a world of appearances, of "absolutely nothingness" 21 . In this case, the affirmative value of creation rests on the denial of reality in general. Again, it is far from clear if writing is a subconscious journey to a world of perfect forms or the awareness of the absence of absolute values, if it involves an expansion of the self or, on the contrary, an endeavour to transcend it through fixity, if it represents a creation within the creation, an attempt to improve reality or to counter its alleged unreality.

"Too ordinary and too essential", as Dan Petrașincu claims, the question "why do you write?" finds a possible answer in an article by Marin Sorescu published in 1989 under the title "How Do We Happen to Be Inspired?". Sheer haphazard, ordinary fact and nothing more arouse inspiration, through an unpredictable and fatally inexplicable "ricochet". "You write better when you don't want to write", the poet explains. "You don't write when you really want to write, when you sit

\footnotetext{
${ }^{19}$ Ibidem, p. 125.

${ }^{20}$ Ibidem, p. 133.

${ }^{21}$ Ibidem, p. 62.
} 
down at the desk planning to be brilliant. You are caught unawares by slivers of inspiration, always on the wrong foot, always when you're running to catch a tram, when you're at the market. Fatigue is a good conduit for inspiration"22. Talent, as a renewed search for complete self-expression, inevitably involves an absence and a negation, visible both in the text and in all the subtexts of the literary work.

\section{BIBLIOGRAPHY}

CIORAN, Emil, Caiete I (1957-1965) [Notebooks I (1957-1965)]. Foreword by Simone Boué. Translated from the French by Emanoil Marcu and Vlad Russo, Bucureşti, Humanitas, 1999-2000.

ELIADE, Mircea, "Insuficienţa literaturii" ["The Insufficiency of Literature"], in Profetism românesc [Romanian Profetism], I, Bucureşti, Roza vânturilor, 1990, pp. 43-47.

HRIMIUC-TOPORAŞ, Gheorghe, DURNEA, Victor, ed., „De ce scrieți?” Anchete literare din anii '30 ["Why Do You Write?" Literary Surveys from the 1930s]. Forewords, notes and name index by Victor Durnea, Iaşi, Polirom, 1998.

SORESCU, Marin, "Cum se întâmplă că suntem inspiraţi?" [“How Do We Happen to Be Inspired?"], Ramuri, 1989, 8 (302), p. 7.

\section{"HOW DO WE HAPPEN TO BE INSPIRED?" LITERATURE SURVEYS FROM THE 1930s (Abstract)}

The question of creative inspiration, pertaining to aesthetics, poetics and the philosophy of culture, became the subject of literary review debates in the interwar period, in the context of a growing concern for authenticity. Under the title "Why Do You Write?" the literary review Facla launched a survey on this issue in 1935, to which over two hundred literati responded. The result was a genuine novel about writing, conveyed in the form of a cultural chronicle of those times. Extremely diverse, the answers oscillated among a multitude of perspectives ranging from empirical to social, political, psychological, metaphysical or mystical, raising, in fact, as many question marks. The discourse coordinates were framed by the register of interrogation and negation, through the cultivation of irony, paradox and the anti-literary profession of faith.

Keywords: inspiration, creation, survey, negation, authenticity.

\footnotetext{
${ }^{22}$ Marin Sorescu, “Cum se întâmplă că suntem inspirați?" [“How Do We Happen to Be Inspired?”],
} Ramuri, 1989, 8 (302), p. 7. 


\section{„CUM SE ÎNTÂMPLĂ CĂ SUNTEM INSPIRAȚI?” ANCHETE LITERARE DIN ANII 1930 \\ (Rezumat)}

Problema inspiraţiei creatoare, apanaj al esteticii, poeticii şi filosofiei culturii, devine obiectul unor dezbateri revuistice în perioada interbelică, în contextul preocupării pentru autenticitate. Sub titlul De ce scrieţi? revista Facla iniţiază în anul 1935 o anchetă pe această temă, la care participă peste două sute de literaţi. Ceea ce rezultă este un mic roman al scriiturii, sub forma unei cronici culturale de epocă. Extrem de diverse, răspunsurile oscilează între o multitudine de perspective, de la domeniul empiric la cel social, politic, psihologic, metafizic sau mistic, lăsând în urma lor tot atâtea semne de întrebare. Coordonatele discursului se păstrează constant în registrele interogaţiei şi negaţiei, prin cultivarea ironiei, paradoxului şi a profesiunii de credinţă antiliterară.

Cuvinte-cheie: inspiraţie, creaţie, anchetă, negaţie, autenticitate. 